of Natural Sciences, and a life-long member of it. To him also is due the credit of establishing the Buffalo Botanic Garden, in which he was particularly interested.

His library was a notable one, as he was a collector of rare discrimination, and the works on botany were many and valuable. In addition to the more pretentious volumes, a large collection of pamphlets was accumulated, among which appear a very large number of local catalogues. These books of botanical interest, as well as his collections of living plants and herbarium specimens, he was preparing to transfer to the Botanic Garden when he was stricken down.

Mr. Day had for years been a member of the Park Commission of his city, and drew the act which created the Park department. In this act, drawn thirty years ago, he made provision for both botanical and zoological collections, both of which, after years of waiting, he saw established.

His loss will be mourned by the many botanists of his acquaintance, as well as by his fellow-citizens, by whom he was held in high esteem. - John F. Cowell, Buffalo Botanic Garden.

\title{
OBSERVATIONS ON THE ROOT SYSTEM OF CERTAIN CACTACEÆ.
}

ThOSE who make botanical trips into arid regions do so generally with the one idea of collecting material to be worked up at leisure in laboratories or herbaria, or to be deposited in botanic gardens. Their stay, as a rule, is closely limited, and the necessity of covering a great amount of ground brings with it a tendency to pass over those details which take considerable time. The root system of desert plants, both as regards structure and distribution of roots, is one of those questions which has perforce been to a great extent neglected, our knowledge, generally speaking, being confined to the examination of the amount of underground growth collected with herbarium specimens. Therefore it seemed to me worth while during my stay in Tucson, Arizona, in the midst of the great cactus plains, to make a rather careful study of the roots of certain large forms which could scarcely be preserved in toto.

The root systems of Cactaceæ, in general, are somewhat smaller than would be expected. The distribution, however, is such as in a way to make good the deficiency in size and length. The specific 
examples here cited may be fairly taken, I think, as types, as without exception they agree in general characters.

Echinocactus Wislizeni Engelm.-Plants about $7.5^{\mathrm{dm}}$ high and 3.5 to $4^{\mathrm{dm}}$ in diameter gave the following results. Three or four main roots, Io to $\mathrm{I} 2^{\mathrm{mm}}$ thick, branch out horizontally from beneath the plant, taper but slightly, are sinuous and much branched at the tips, in such a manner as pretty thoroughly to cover the ground about the plant within a radius of 2.4 . The fine rootlets are very numerous, generally turning upward. In no place does this set of roots run much more than $10^{\text {cin }}$ below the surface. Just beneath the plant are a few small roots passing almost directly downward, tapering very rapidly, and with numerous branchings penetrating to the depth of scarcely $30^{\mathrm{cm}}$.

Opuntia fulgida Engelm.-An arborescent form. A specimen about ${ }^{\mathrm{d}} 5^{\mathrm{dm}}$ high, considerably branched, showed, as in the above case, several long slender roots with fine branches, running horizontally 5 to $10^{\mathrm{cm}}$ below the surface, and covering an area with a radius of $30^{\mathrm{dm}}$ about the plant. In a plant of O. fulgidla mamillata (Schott) Coulter, which was washed by a small torrent, these roots appeared above ground in many places. In both of these specimens a few quickly tapering roots were demonstrated at the base of the plant, passing directly downward to the depth of about a foot.

Opuntia Whipplei Engelm. showed a similar state of affairs.

A Platopuntia (O. angustata Engelm.?) possessed much the same characters. The prostrate younger joints here send out roots and reproduce by innovation, ${ }^{\text {I }}$ but the chief roots are to be found attached to the oldest living joint. At this point a double system can be seen, consisting of a couple of large roots, horizontal and but slightly below the surface, and one or two much smaller roots passing downward with rapid branching.

Cereus giganteus Engelm.-This plant thrives on rocky hillsides, and its root system is modified somewhat by conditions of soil and slope. In the specimen examined the roots which passed directly downward came very quickly in contact with a flaky bedrock, into the crevices of which they sent their branches, sometimes causing a splitting off of fragments. Although these roots seemed to pass scarcely three feet downward, their hold was exceedingly firm. The horizontal roots were directed almost entirely up the slope, sometimes appearing on the surface, but often descending to some little depth to avoid large

x Toumey, J. W. : Vegetal dissemination in Opuntia. Bот. Gaz. $20: 356$. 1895. 
bowlders. The area which they covered extended about $45^{\mathrm{dm}}$ away from the plant, which was between $\mathrm{I} 2$ and $5^{\mathrm{m}}$ high.

Cereus enneacanthus Engelm. - This rather ascending, cespitose form showed, as in the other cases, the two sets of roots; horizontal, long and sinuous; and vertical, abruptly tapering and much-branched. Several specimens were examined.

Conclusions. - In the majority of the larger Cactaceæ there are two distinct root systems - one horizontal, for absorptive purposes; the other passing downward, for anchorage. The depth of the horizontal system varies with the degree of penetration of surface water, which, in turn, is to some extent dependent on the character of the soil. One of the specimens of Echinocactus was examined the day following a gentle rain which had continued intermittently for two days, thus giving the water time to soak in as it fell. The soil was dampened to a distance of about four inches below the surface, just the depth of the absorptive root system.

Observations upon young plants of Opuntia fulgida give the following as the sequence of root formation. The first to be developed by joint or seedling are the vertical roots, which for a time act both for absorption and anchorage. As the plant increases in size the ground directly beneath it is shielded from moisture by its body, and in order to get the necessary food material the horizontal system is developed secondarily, starting, as a rule, directly from the stem, but occasionally appearing in part as horizontal branches of vertical roots. This horizontal system covers an area far greater than that sheltered by the parts above ground. As the soil is generally firm, and the horizontal roots give some support, there is little need for any roots to descend to a great depth. The small amount of surface exposed to winds may be considered another reason for this.

Correlated with the difference in distribution of the two systems is a difference in structure, as may be proved by a most superficial examination. The horizontal roots are in all cases extremely brittle, the vertical much more elastic and capable of withstanding far greater tension. The woody cylinder in large absorptive roots is far smaller relatively than that of the anchoring roots. Microscopically this difference may be most easily seen in the secondary xylem. For this examination sections of roots of Opuntia fulgida and Echinocactus Wislizeni were used. The xylem of the absorptive root is composed mainly of ducts, that of the anchoring roots, which, after the appearance of the 
horizontal system, seem to have developed for this purpose entirely, consists almost wholly of wood cells. Owing probably to the general evenness of climate the annual rings are not easily demonstrated.Carleton E. Preston, Harvard University.

\section{NON SEXUAL PROPAGATION OF OPUNTIA.}

Professor Toumey, in an article in the Botanical Gazette $(20: 356$. I 895), speaks in general terms of the use of spines as aids in dissemination of opuntias which are dispersed by the breaking off of the separate joints. A short note may be added as to the function of these spines, especially in such long-spined species as O. fulgida Engelm. A joint falling upon the sand very often rebounds from the elasticity of the spines, and by this impetus is carried some distance from the parent plant. The greatest aid, however, is in the placing of the joint. Joints destined for such dissemination are as a rule obovate, the best developed areolae with the longest spines being situated on the distal end, those of the proximal end being scarcely at all armed. The result of this is that the joint upon falling almost invariably lights with its base downward, in the best possible position for striking root. The distal parts are kept off the ground in all cases by the long spines.-Carleton E. Preston, Harvard University.

\section{GAURELLA $=$ GAUROPSIS.}

I HAVE to propose the restoration of the name of Gauropsis Torrey \& Fremont (Rep. 315. I845), to take the place of Gaurella Small (Bull. Torr. Bot. Club 23: 183. I 896). Gauropsis was clearly defined by its authors, though not treated as a genus, and the type and only species was the CEnothera canescens Torrey \& Fremont, described at the place cited. The Index Kewensis gives Gauropsis Presl, I 849 ; I have not seen Presl's work, but in any event it is later than that of 'Torrey and Fremont. The type species of Gauropsis, Gaurella guttulata (Geyer) Small will become Gauropsis guttulata, or, I think, much better Gauropsis canescens, since the name canescens is only preoccupied by a slight variety of Enothera biennis.-T. D. A. Cockerell, East Las Vegas, N. M. 